\title{
PreEMPTIVE Legislation IN THE EuROPEAN UNION AND THE UNITED STATES ON THE TOPIC OF NANOMEDICINE: EXAMINING THE QUESTIONS RAISED BY SMART MEDICAL TECHNOLOGY
}

\author{
Emilee S. Preble*
}

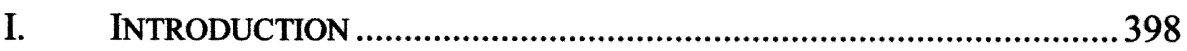

II. HISTORICAL OVERVIEW AND THE TROUBLE WITH REGULATING NEW TECHNOLOGIES.

A. Nanotechnology and the Development of Nanomedicine ......... 399

1. What is nanotechnology? .................................................... 399

2. What is Nanomedicine?.......................................................400

B. Factual Scenario of Patient X-Tumor Cured by Nanites ...... 401

C. Regulating the Undiscovered - Controlling the Unknown....... 402

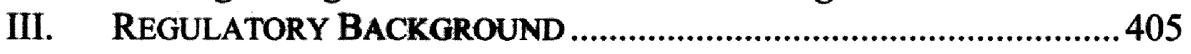

A. Regulation in the United States................................................. 405

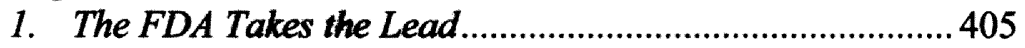

2. The Nanotechnology Task Force.......................................407

3. Special Interest Groups in the United States Advocating for Regulation

4. Opposition to Nanotechnology Research and Development in the United States...............................................................412

B. Regulation in the European Union ......................................... 413

1. Current Regulatory Scheme ................................................. 413

2. Designated Regulatory Groups and Agencies Drafting

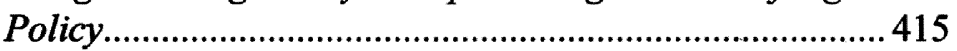

3. Considering Regulation....................................................... 416

4. Focus of Research and Development ................................. 417

III. ANALYSIS: STRATEGY FOR GOVERNANCE OVER NANOMEDICINE417

A. The Trouble with Regulating Too Early ....................................417

1. In the United States ............................................................. 417

2. In the European Union...................................................... 419

B. Fixing the Focus on Research and Development ..................... 421

C. Dealing with the Ethical Conundrum Surrounding the Unknown in Nanomedicine.

1. Contemporary Comparison to a Medical and Ethical Dilemma.

2. Creation of a Task Force on Ethical Considerations......... 424

* J. D., 2009, Indiana University School of Law-Indianapolis; B.A., 2005, Butler 
IV. CONCLUSION 424

Every industry that involves manufactured items will be impacted by nanotechnology research. Everything can be made in some way better-stronger, lighter, cheaper, easier to recycle-if it's engineered and manufactured at the nanometer scale. ${ }^{1}$

\section{INTRODUCTION}

Poised at the forefront of scientific and technological research and advancement, nanotechnology involves sophisticated, microscopic technologies that seek to manipulate matter on a molecular level. Theoretically, these bits of nanotechnology (nanites) can be programmed, either through their molecular make-up, chemical composition, or through instructive coding, to perform many designed objectives. Essentially, nanites can be programmed to do anything at all. Although nanotechnology could be useful in virtually any industry, it has the potential to be extremely valuable in the medical field. Nanites could be used to perform countless functions in health care, including the eradication of cancer-causing cells, restoration of eyesight, stimulation of the immune system, and even destruction of tumors.

Nanotechnology in the medical field, termed nanomedicine, is a topic with which many of the world's leading nations have already begun to wrestle. In 2004, the European Commission ("EC") affirmatively decided to consider nanotechnology and nanomedicine as topics of the utmost importance with the adoption of the Communication ${ }^{2}$ entitled "Towards a European Strategy for Nanotechnology."3 The Communication pushed the nanotechnology issue to the institutional level, facilitating the development of a comprehensive European strategy for dealing with the arrival of nanotechnology. ${ }^{4}$ The formation of a specific subcommittee to research and plan for the arrival of nanotechnology demonstrates the considerable time and manpower the EC has invested in its efforts to anticipate the big arrival of

1. Stan Williams, Director of Quantum Science Research, HP Labs, Newbridge Institutional Research, http://www.newbridgereports.com/quotes.html (last visited Nov. 1, 2008).

2. The European Commission functions as the executive branch of the European Union. "The Commission's job is to represent the common European interest to all the EU countries. To allow it to play its role as 'guardian of the treaties' and defender of the general interest, the Commission also has the right of initiative in the lawmaking process." The European Commission utilizes Communications to disseminate policy, goals, and directives to the larger European Community. The European Commission at Work, http://ec.europa.eu/ atwork/basicfacts/index_en.htm\#comm (last visited Jan. 18, 2009).

3. The European Strategy for Nanotechnology and the Nanotechnology Action Plan, http://cordis.europa.eu/nanotechnology/actionplan.htm (last visited Jan. 17, 2009).

4. Id. 
science's smallest technologies.

In the United States, regulatory agencies such as the Food and Drug Administration ("FDA") have already begun to formulate frameworks to address emerging issues presented by nanomedicine. Since the beginning of the George W. Bush Administration, a great deal of emphasis has been placed on nanotechnology research and development. Notably, the Bush Administration facilitated the creation of the National Nanotechnology Initiative ${ }^{5}$ which receives large amounts of federal funding each year, including an estimated budget of $\$ 1.5$ billion dollars in $2009 .^{6}$

This note will take an in-depth look at existing regulatory frameworks concerning nanotechnology and nanomedicine in the United States ("U.S") and the European Union ("EU"). It will consider the policy rationales that both nations have relied upon to justify use of their current regulatory systems dealing with nanotechnology and nanomedicine. This note will also consider any additional steps or measures that the US and the EU have taken with regard to nanotechnology. This note seeks to evaluate how regulatory schemes can best maximize the benefits that nanotechnology and nanomedicine will give to society, while simultaneously anticipating and minimizing any negative effects such technology might have. Most importantly, this note will attempt to determine if these regulations stifle the advancement and development of nanotechnologies.

\section{HistoricAl OVERVIEW AND THE TROUBLE WITH REgUlating NEW TECHNOLOGIES}

\section{A. Nanotechnology and the Development of Nanomedicine}

\section{What is nanotechnology?}

The prefix "nano" is a derivative of the term 'nanos' in Greek, meaning dwarf. "Nano" is also a prefix used in the metric system of measurement to describe a specific unit of measure - a nanometer is one billionth of a meter. ${ }^{8}$ Nanotechnology is technology that is created and functions on this extremely tiny, or dwarf, scale (the nanoscale). An example of the size of the nanoscale would be something " $1 / 80,000^{\text {th }}$ of the diameter of a human hair, or 10 times the diameter of a hydrogen atom."9 Regardless of

5. Brian Wilhelmi, Nanosilver: A Test for Nanotech Regulation, 63 FoOD \& DRUG L.J. 89,99 (2008)

6. Id. For a closer examination of the 2007-2009 funding break-down, see chart, infra Part II(A)(3).

7. M. Lupton, Nanotechnology - Salvation or Damnation for Humans?, 26 MED. \& L., 349, 350 (2007).

8. Id.

9. Id. citing BBC News Science/Nature, www.bbc.com; "The Smaller is Better" in Reason, www.keepmedia.com 
how specifically it is measured, nanotechnology is small, very small.

Nanotechnology development can be broken down into two distinct scientific approaches: the top down approach and the bottom up approach. ${ }^{10}$ The top down approach involves the creation of a structure on the nanoscale. ${ }^{11}$ These creations would be machines of sorts that were produced by other machines or etching techniques. ${ }^{12}$ In contrast, the bottom up approach involves the construction of technology atom-by-atom or molecule-bymolecule out of organic and inorganic matter. ${ }^{13}$ This approach, also referred to as molecular nanotechnology, is more firmly rooted in biology. ${ }^{14}$ Not surprisingly, molecular nanotechnology is easily the most advanced form of nanotechnology. ${ }^{15}$ It not only involves the construction of engineered organic matter on the small nanoscale, but also the ability to program and sustain this organic matter to perform specific tasks over a period of time. ${ }^{16}$

\section{What is Nanomedicine?}

The National Institute for Health (NIH) defines nanomedicine as "an offshoot of nanotechnology, [that] refers to highly specific medical intervention at the molecular scale for curing disease or repairing damaged tissues, such as bone, muscle, or nerve."17 Similarly, the European Technology Platform (ETP) ${ }^{18}$ defines nanomedicine as technology that "exploits the improved and often novel physical, chemical and biological properties of materials at the nanometer scale. Nanomedicine has the potential to enable early detection and prevention, and to essentially improve diagnosis, treatment and follow-up of diseases." 19 Unlike conventional medicine of today, "[n]anomedicine would facilitate the repair and improvement of the human body from the inside out, with a precision and delicacy far greater than the finest surgical instruments permit." 20

10. Lupton, supra note 7 , at 350 .

11. Id. at 351 .

12. This type of nanotechnology is best thought of as akin to microscopic robots or machines that were constructed out of raw materials and assembled by other machines. Id.

13. Lupton, supra note 7 , at 351.

14. Id.

15. Id.

16. Id. (providing an example through the creation of "tiny living robots, called biobots." Id.)

17. The NIH Common Fund, Nanomedicine, http://nihroadmap.nih.gov/nanomedicine/ (last visited Nov. 8, 2008).

18. "The members of the ETP are stakeholder organisations in the field of Nanomedicine including large industry, SMEs, industrial associations, research institutions, academia, hospitals and others." European Technology Platform, Membership, http://www.etpnanomedicine.eu/public/about/membership (last visited Mar. 14, 2009).

19. European Technology Platform, http://www.etp-nanomedicine.eu/public (last visited Nov. 8, 2008).

20. Lupton, supra note 7 , at 351 . 
Though these uses for nanomedicine have yet to reach beyond the theoretical in many respects, there are current advancements in this area of research. Professor Carlo Montemagno, of the University of California, has created tiny robots that are, for all intents and purposes, alive. ${ }^{21}$ In describing his work, Professor Montemagno stated "...the cells actually grow, multiply and assemble on their own. The device is alive."22 Professor Montemagno created these robots by growing rat cells onto silicon computer chips. ${ }^{23}$ These robots, which are less than a millimeter long, can move themselves around without any external power source, and instead power themselves through the energy gained by contracting cells. ${ }^{24}$ When viewed under a microscope, Professor Montemagno's creations look like "tiny, two footed 'bio-bots." 25 The nanotechnologies he has created are a combination of both the top-down and bottom-up approaches. ${ }^{26}$

Nanotechnology with the ability to power itself and perform various instructed tasks could be utilized in a variety of ways in the medical field. Multiple nanites released into an individual could theoretically communicate with each other to determine how to maneuver throughout the very complex human body. ${ }^{27}$ Further, the nanites would theoretically be able to hone in on existing problems and predict where future problems might occur. $^{28}$ Collaboration between nanites would be an unprecedented, revolutionary form of medical treatment. While performing all of these tasks the nanites would be able to communicate with one another to coordinate their efforts in the body. ${ }^{29}$ An example of this coordinated effort is explored in the next section.

\section{B. Factual Scenario of Patient X-Tumor Cured by Nanites}

Patient $\mathrm{X}$ is currently being treated for a cancerous tumor with currently known methods, such as chemotherapy and radiation. These treatments are only moderately helpful in treating Patient X's tumor, and have serious and undesirable side effects. ${ }^{30}$ Patient $\mathrm{X}$ may ultimately win or lose

21. Id.

22. Id.

23. Id.

24. Id.

25. $I d$.

26. Lupton, supra note 7 , at 350 .

27. "[I]n the young field of nanotechnology, scientists and engineers are taking control of atoms and molecules individually, manipulating them and putting them to use with an extraordinary degree of precision." Adam Keiper, The Nanotechnology Revolution, 2003 THE NEW ATLANTIS, 17, 17, available at http://www.thenewatlantis.com/publications/thenanotechnology-revolution.

28. Id. at 24-5.

29. Id. at 25 .

30. Mayo Clinic, Cancer Survivors: Managing Late Effects of Cancer Treatment, http://www.mayoclinic.com/health/cancer-survivor/CA00073 (last visited Jan. 18, 2009). 
her battle with cancer, but, regardless of the outcome, it is certain that Patient X's battle will not be short. Enduring months, even years, of harsh and potentially damaging medical treatments will undoubtedly take its toll on Patient X.

Now suppose that Patient $X$ has the same type of cancerous tumor, only this time Patient $X$ lives in a world where nanomedicine exists. Once Patient X's doctor becomes aware of the tumor, she is now able to rely on a different form of treatment for Patient X's cancer, nanomedicine. The treatment would be greatly different than chemotherapy and radiation. It would involve nanites, or microscopic robots that would be programmed to treat and cure the tumor. The nanites would be instructed to attack and destroy Patient X's tumor. Once the nanites are injected into Patient $X$ they begin to perform their programmed task. Patient $X$ would be able to overcome a battle with cancer quickly, and with much less suffering than previous known medical treatments.

Though the science has yet to specifically develop the type of technology that would make this factual scenario possible, the case of Patient $X$ is a hypothetically plausible use of nanomedicine in medical treatment. This Note will continue to reference the above scenario to explore possible difficulties, concerns, and benefits surrounding implementation and use of nanomedicine.

\section{Regulating the Undiscovered - Controlling the Unknown}

Nanotechnology and nanomedicine is vexing to governments and regulatory agencies for precisely the same reason it elicits such excitement among innovators in the scientific and medical fields: the possibilities and potential risks of nanomedicine have yet to be imagined. This section highlights areas of concern with regard to nanotechnologies - how the technology is vulnerable and what risks those vulnerabilities introduce.

Cosmetic companies are concerned about the future of nanotechnology in their industry because they believe it is possible for nanoparticle contaminants to find a way into their products and eventually make it into a person's blood stream through use of their cosmetics. ${ }^{31}$ Potentially, the nanoparticle contaminants will have detrimental effects. ${ }^{32}$ Although the nanoparticle contaminants considered here are not necessarily nanites, that is,

31. " $[\mathrm{N}]$ ew nanotechnologies are being widely deployed in cosmetics products, despite evidence of serious potential health risks... [T] he physical application of some of the nanotechnologies to the body in cosmetics makes these uses uniquely prone to skin penetration, inhalation and ingestion of the nanotech materials." TIM LITTLE, SANFORD LEWIS \& PAMELA LUNDQUist, BENEATH THE SKIN: HIDDEN LIABILITIES, MARKET RISK AND DRIVERS OF Change in the Cosmetics and Person Care Products Industry 2 (2007), available at http://iehn.org/filesalt/IEHNCosmeticsReportFin.pdf [hereinafter BENEATH THE SKIN].

32. See id; see also Nanowerk, New Report Slams Nanotechnology in Cosmetics, http://www.nanowerk.com/news/newsid=1505.php (last visited Nov. 2, 2008). 
they may not be programmed with a specific purpose, it does demonstrate the fear that surrounds the unknown effects that these tiny particles could have on human physiology. ${ }^{33}$ Imagine, a woman gets up in the morning and applies her make-up as usual and subsequently becomes violently ill due to a nanoparticle contaminant. ${ }^{34}$ There are currently no ways of detecting these contaminants. As a result, physicians will face difficulty in treating the woman because they will not be able to determine the source of the patient's illness. ${ }^{35}$ Additionally, even if the source of her illness can be ascertained for treatment purposes, the challenge of determining who should be liable for her illness remains. Though the nanoparticle contaminants are not directly related to nanomedicine, this situation demonstrates the potential risks matter created on the nano-level present to the medical field.

Another very real fear surrounding nanomedicine addressed the potential affects on human toxicology. "The lack of knowledge about how nanoparticles might affect or interfere with the biochemical pathways and processes of the human body" remains unknown. ${ }^{36}$ It is possible that nanomedicine could be extremely harmful to human physiology. The European Technology Platform on Nanomedicine notes some fears in its Vision Report: "The risks and challenges of NanoMedicine comprise issues of toxicity and carcinogenicity, as well as long-term stability and excretion pathways for artificial nanostructures, and technological challenges in molecular manufacturing, quality assurance and eventually, the programmability of nanodevices." 37 One report aptly articulated that the danger of nanotechnology is precisely in the fact that we do not know what the dangers are...they remain unknown. ${ }^{38}$ It is difficult to anticipate the effects, harms,

33. See Wilhelmi, supra note $\mathbf{5}$, at 97 (discussing the drastically different effects that nanoparticles with even the smallest degree of compositional variance from their largermolecule counterparts can have on surrounding material).

34. BENEATH THE SKIN, supra note 31 , at 2 .

$[\mathrm{M}]$ any potentially harmful chemicals have been found to make their way into cosmetics and personal care products. The threats to health may include...cancer, harm to developing fetuses and infants exposed to the chemicals through baby products or their mother's cosmetics use, and disruptions of various organ or hormonal systems in the body. Id.

35. Id.

36. Nanowerk, The Potential and the Pitfalls of Nanomedicine (May 7, 2007), http://www.nanowerk.com/spotlight/spotid=1891.php (last visited September 22, 2009) [hereinafter Potential Pitfalls].

37. European Technology Platform on Nanomedicine, Vision Paper and Basis for a Strategic Research Agenda for Nanomedicine, 12 (Sept. 2005) available at $\mathrm{ftp}$ ///ftp.cordis.europa.eu/pub/nanotechnology/docs/nanomedicine_visionpaper.pdf.

38. Rick Weiss, Nanotechnology Risks Unknown, THE WASHINGTON POST, Sept. 26, 2006, available at http://www.washingtonpost.com/wp-dyn/content/article/2006/09/25/ AR2006092501138.html (noting that "[a]bout 300 consumer products already contain nanoscale ingredients..., including several foods and many cosmetics, with little or no research to document their safety"). 
and benefits of a product so new in its conception when even those who are most familiar with it can do little more than theorize as to its outcomes and application.

Perhaps these reasons account for the fact that many current discussions on nanotechnology are steeped in complex ethical issues. ${ }^{39}$ Topping this list of ethical concerns is the way in which nanotechnology will likely be able to permit human enhancement. The potential use of nanotechnology for human enhancement blurs the lines between medical and nonmedical uses of the technology. ${ }^{40}$ Nanomedicine could not only cure Patient X's cancer, it could make her stronger, more energetic, or improve other physiological characteristics in ways that stretch far beyond the original goal of eradicating her cancer. What would further complicate the issue is if Patient X purchased the nanites used to cure her cancer. She would then own them and could theoretically have them reprogrammed to perform any function she desired. Suddenly, the absence of an ethical line in the sand becomes quite noticeable. The question of whether Patient $X$ should be able to do with her nanites what she chooses becomes important to answer.

Some theoretical applications for nanomedicine are extremely attractive. Consider Robert A. Freitas ${ }^{41}$ proposed use of artificial red blood cells. $^{42}$. His fabricated cells are theorized to "be capable of delivering oxygen [to the human body] many hundreds of times more efficiently than human red blood cells." ${ }^{43}$ Respiratory diseases would likely be eradicated with this technology. ${ }^{44}$ Transfusions from real blood donors would be unnecessary. ${ }^{45}$ Athletes could increase their endurance; scuba divers could hold their breath underwater for hours at a time. ${ }^{46}$ This would all be possible because of nanomedicine.

These possible uses of nanomedicine raise ethical concerns in the form of human enhancement, which will be discussed later in this Note. Nevertheless, nanotechnology and nanomedicine still remain a hopeful promise of numerous benefits slated for the future horizon in terms of medical treatment. Regulators and legislators must remain ever cognizant of the ethical concerns surrounding nanomedicine. They will certainly be tasked

39. Potential Pitfalls, supra note 36.

40. Id.

41. "Robert A. Freitas Jr. ...authored the first detailed technical design study of a medical nanorobot ever published in a peer-reviewed mainstream biomedical journal... [and] is the author of Nanomedicine, the first book-length technical discussion of the potential medical applications of molecular nanotechnology and medical nanorobotics." Institute for Molecular Manufacturing, Robert A. Frietas Jr., Senior Research Fellow, http://www.imm.org/ about/freitas/ (last visited Mar. 12, 2009).

42. Keiper, supra note 27, at 25.

43. Id.

44. Id.

45. Id.

46. Id. 
with the delicate and difficult choices that determine who we are and what we ought to be able to permit ourselves to become. At this moment, "[a]s the science of [nanotechnology] leaps ahead, the ethics lag[] behind."

\section{REGULATORY BACKGROUND}

\section{A. Regulation in the United States}

On December 3, 2003, President George W. Bush signed the Nanotechology Research and Development Act (NRDA). ${ }^{48}$ The NRDA authorized funding for nanotechnology research for a period of four years beginning in fiscal year $2005 .^{49}$ This funding was spread across ten federal agencies and totaled approximately $\$ 849$ million. ${ }^{50}$ Nanotechnology research and development "has been a priority for the Administration for the last three years." $"$ In fiscal year 2009, federal funding for this initiative totaled $\$ 1.5$ billion dollars. ${ }^{52}$ In addition to this program, other federal agencies have stepped up to tackle the topic of nanotechnology regulations.

\section{The FDA Takes the Lead}

The FDA is a federal agency within the United States Department of Health and Human Services. ${ }^{53}$ It is charged with the safety regulation of food, drugs, medical devices, etc. used and consumed by the American populace. ${ }^{54}$ Historically, the FDA has been successful in regulating new technologies - especially in the field of biotechnology. ${ }^{55}$ The FDA is extremely important to the development of nanotechnology and nanomedicine, because most new products that would employ this technology would require

47. Anisa Mnyusiwalla, Abdallah S. Daar \& Peter A. Singer, 'Mind the Gap': Science and Ethics in Nanotechnology, 14 NANOTECHNOLOGY R9, R9 (2003), available at http://www.iop.org/EJ/article/0957-4484/14/3/201/t303R1.pdf.

48. The White House, http://www.whitehouse.gov/news/releases/2003/12/200312037.html (last visited Nov. 2, 2008).

49. Id.

50. Id.

51. The White House, http://www.whitehouse.gov/news/releases/2003/12/200312037.html (last visited Nov. 2, 2008) (noting that the funding for nanotechnology research and development has gone up $83 \%$ since 2001 ).

52. National Nanotechnology Initiative (NNI), Funding, http://www.nano.gov/html/ about/funding.html (last visited Jan. 16, 2009).

53. U.S. Food \& Drug Administration, About FDA: Centers \& Offices, http:// www.fda.gov/AboutFDA/CentersOffices/default.htm (last visited Sept. 24, 2009) [hereinafter "About FDA"].

54. Id.

55. John Miller, Student Note, Beyond Biotechnology: FDA Regulation of Nanomedicine, 4 COLUM. SCI. \& TECH. L. REV. 1, 2 (2003) (discussing the FDA's past success with regulations on biotechnology, but noting that nanomedicine will present a new challenge in regulation). 
FDA approval before public consumption and use. ${ }^{56}$

The FDA is involved in the field of nanotechnology in a variety of ways. ${ }^{57}$ Through the use of both internal and external working groups, the FDA remains educated and aware of the progress of the nanotech industry. ${ }^{58}$ Though a regulatory agency, the FDA remains engaged in areas of research surrounding nanotechnology. This research is not developmental in nature, but rather, is used to determine the characteristics of nanotechnology and focuses on understanding how nanotechnology interacts with other FDA-approved products. ${ }^{59}$

The FDA has also tentatively responded to the question surrounding jurisdiction over nanotechnology products. ${ }^{60}$ Categorization options under the FDA are drugs, devices, biologics, or some combination thereof. ${ }^{61}$ Currently, the belief is that nanotechnologies will be products comprised of a combination of the above three. $^{62}$ Troublesome for the FDA is that many of their different centers across the country regulate combination products differently. ${ }^{63}$ Predictability and consistency in regulation are only a few of the concerns posed by this managerial nightmare. ${ }^{64}$

Since the FDA stipulates the requirements and guidelines for the majority of products in the U.S., it follows that the FDA is the most suited at this time to tackle nanotechnology regulation. ${ }^{65}$ The FDA responded to a question about the risks of nanotechnology and whether or not these technologies should be regulated differently:

Existing requirements may be adequate for most nanotechnology products that we will regulate. These products are in the same size-range as the cells and molecules with which FDA reviewers and scientists associate every day. In particular, every degradable medical device or injectable pharmaceutical generates particulates that pass through this size range during the processes of their absorption and elimination by

56. Jessica K Fender, Student Note, The FDA and Nano: Big Problems with Tiny Technology, 83 CHI.-KENT L. REV. 1063, 1065-66 (2008).

57. Nakissa Sadrieh \& Parvaneh Espandiari, Nanotechnology and the FDA: What are the Scientific and Regulatory Considerations for Products Containing Nanomterials?, 3 NANOTECHNOLOGY L. \& BUS. 339, 341-45 (2006).

58. Id. at 341-42.

59. Id. at 342 .

60. U.S. Food \& Drug Administration, Science \& Research: Frequently Asked Questions, http://www.fda.gov/scienceresearch/specialtopics/nanotechnology/frequentlyaskedquestions/ default.htm (last visited Nov. 1, 2008) [hereinafter FDA Nanotechnology FAQ].

61. Sadrieh \& Espandiari, supra note 57, at 342.

62. Id. at 343.

63. Id.

64. Id.

65. Id. at 344. 
the body. To date, FDA has no knowledge of reports of adverse reactions related to the "nano" size of resorbable drug or medical device products. If new risks are identified, arising from new materials or manufacturing techniques for example, new tests or other requirements may be needed. $^{66}$

\section{The Nanotechnology Task Force}

In 2006, the FDA formed the Nanotechnology Task Force (NTF), ${ }^{67}$ a body specifically dedicated to "determining regulatory approaches that encourage the continued development of innovative, safe, and effective FDAregulated products that use nanotechnology materials."68 The NTF is comprised of members from each of the FDA Centers. ${ }^{69}$ During a public meeting, NTF co-chair Dr. Randall Lutter said that the NTF would be also creating "guidance documents" for nanotechnology practitioners' use to facilitate a better understanding how the FDA will likely interpret and apply existing laws and regulations to the developing technology. ${ }^{70}$

The NTF has arguably adopted a "wait and see" approach to nanotechnology regulation. In its 2007 report, the NTF focused on the major issues: 1) examining the state of current knowledge regarding nanotechnology; 2) "the FDA's ability to address scientific issues" in products containing nanotechnology; and 3) "describing the regulatory authorities as they relate to nanotechnology in FDA regulated products." "71 The FDA is intentionally avoiding a narrow definition for nanotechnology at this point and does not propose any specific mandates or regulations beyond those currently in place to guide existing technology. ${ }^{72}$ To not completely frustrate those hoping for some direction in terms of future nanotech regulation, the NTF Report offered limited guidance by encouraging a reliance on research and the "predicative value of scientific studies." cient guidance at all.

66. FDA Nanotechnology FAQ, supra note 60.

67. Wilhelmi, supra note 5, at 100 .

68. U.S. Food \& Drug Administration, FDA Nanotechnology Task Force, http:// Www.fda.gov/scienceresearch/specialtopics/nanotechnology/nanotechnologytaskforce/default.htm (last visited Jan. 16, 2009).

69. FDA Centers Include: 1) Center for Biologics Evaluation and Research; 2) Center for Devices and Radiological Health ; 3) Center for Drug Evaluation and Research; 4) Center for Food Safety and Applied Nutrition; 5) Center for Veterinary Medicine; 6) National Center for Toxicological Research; 7) Office of Chief Counsel; 8) Office of the Commissioner; 9) Office of Regulatory Affairs. About FDA, supra note 53; See Wilhelmi, supra note 5, at 100.

70. Wilhelmi, supra note 5 , at 100.

71. Id. at 100-01.

72. Id. at 101 .

73. Id. 
The NTF report also contained an express lack of confidence in current safety testing methods for products used and approved by the FDA as applied to nanotechnology. ${ }^{74}$ Current research that has shed light on electrically neutral silver nanoparticles is illustrative of this point. ${ }^{75}$ Previously, it was believed that nanoparticles would behave essentially the same as their larger, molecular sized counterparts. ${ }^{76}$ Electrically neutral silver nanoparticles have been found, however, to cross plasma membranes with greater ease than their charged counterparts. ${ }^{77}$ This unexpected behavior demonstrates that traditional scientific assumption may not adequately predict how even a simple change in particle size or structure could alter existing chemical, biological, or physiological structures. ${ }^{78}$

Because of the immense uncertainty, the NTF report repeatedly emphasizes the need for collaborative efforts to pool knowledge and resources to lessen the unpredictability of nanotechnology. ${ }^{79}$ The NTF's emphasis on making analyses on "a case-by-case basis" in the summary "recommendations for considerations" sections of the report that were to specifically address how nanotechnology would or would not fit into the current regulatory scheme is indicative of this position. ${ }^{80}$ This "case-by-case" language neatly identifies the FDA's current approach for regulating nanotechnology in its various products as one of "wait and see."

Specific direction as to which FDA regulations would apply to nanotechnology and nanomedicine would be applicable was not given thorough consideration in the NTF Report. Rather, the report focused on the many product types in which nanotechnology will be applicable. ${ }^{81}$ It is likely that this hesitance to focus nanotechnology into one category was also a function of the "wait and see" approach the NTF has taken towards the developing technology.

Still, however, there are certain categories within the FDA that do potentially seem appropriate for nanomedicine as it is anticipated to develop. One notable category with a strong relation to nanomedicine is the device regulation category. Though the use of nanotechnology in pharmaceuticals

74. Id. at 102 .

75. Id.

76. Wilhelmi, supra note 5, at 102.

77. Id. (citing Chun-Nm Lok et al., Silver Nanoparticles: Partial Oxidation and Antibacterial Activities, 12 J. OF BIOLOGICAL INORGANIC CHEM. 527 (2007)).

78. Wilhelmi, supra note 5, at 102.

79. Id. at 103 .

80. U.S. Food and Drug Administration, Nanotechnology: A Report of the U.S. FOOD AND DRUG ADMINISTRATION NANOTECHNOLOGY TASK FORCE 35 (2007), available at http://www.fda.gov/nanotechnology/taskforce/report2007.pdf [hereinafter NTF REPORT].

81. The list included new drugs and biological devices, over the counter monograph drugs, animal drugs and new feed containing animal drugs, devices, food additives and GRAS (generally recognized as safe) food ingredients, color additives, cosmetics, dietary supplements, and labeling and advertising claims for conventional foods and dietary supplements. Id. at 19-20. 
is also extremely relevant to nanomedicine, it remains to be seen whether this technology will be governed by a separate section outside that of medical devices.

Currently, devices regulated under the FDA fall into three categories. ${ }^{82}$ Class I devices are considered low risk and subject to very few controls (labeling, adverse event reporting, etc.). ${ }^{83}$ Class II devices have a higher risk to the public and contain more complex technology. ${ }^{84}$ Devices under this category must follow specific pre-market review protocols wherein a manufacturer must "demonstrate that [its] new device is "substantially equivalent' with regard to safety and effectiveness to a similar device already legally marketed in the United States." ${ }^{.85}$ Class III devices are comprised of the most complex and risky devices available. ${ }^{86}$ These devices are subject to pre-market approval through extensive clinical testing and periodic reporting on new developments. ${ }^{87}$ Alterations to any Class III device require further documentation and testing. ${ }^{88}$ Class III devices are those that pose a "significant risk" to the public. ${ }^{89}$

If forced into an existing category as the FDA and NTF have suggested is appropriate, nanomedicine technology will likely fall into the Class III designation unless another Class division is added to specifically address nanotechnology. The latter option may prove the most appropriate considering the delicate and unpredictable nature of nanotechnology. ${ }^{90} \mathrm{At}$ this point, the "wait and see" approach still applies.

\section{Special Interest Groups in the United States Advocating for Regulation}

In addition to the efforts spearheaded by the FDA, there are other agencies currently operating in the U.S. that focus on nanotechnology. One such organization is the National Nanotechnology Initiative (NNI), which was established in 2001 to coordinate research and development efforts on nanotechnology at the federal level. ${ }^{91}$ The goals of NNI are to "[a]dvance a

82. Id. at 24 .

83. Id.

84. Id.

85. Id.

86. Id.

87. NTF REPORT, supra note 80 , at 24-5.

88. Id. at 25 .

89. "Significant risk devices may include implants, devices that support or sustain human life, and devices that are substantially important in diagnosing, curing, mitigating or treating disease or in preventing impairment to human health. Examples include sutures, cardiac pacemakers, hydrocephalus shunts, and orthopedic implants." Id.

90. See Wilhelmi, supra note 5, at 102 (discussing how the smallest change in the molecular structure of nanoparticles drastically affects the way nanoparticles behave and interact with surrounding matter).

91. National Nanotechnology Initiative (NNI), http:/www.nano.gov/html/about/home about.html (last visited Nov. 2, 2008). 
world-class nanotechnology research and development program[;] [f]oster the transfer of new technologies into products for commercial and public benefit[;] [d]evelop and sustain educational resources, a skilled workforce, and the supporting infrastructure and tools to advance technology[; and] [s]upport responsible development of nanotechnology." ${ }^{92}$ Further, the NNI is committed to the expansion of "scientific understanding of the nanometer scale phenomena." 93

NNI is governed and coordinated by the Nanoscale Science, Engineering and Technology (NSET) Subcommittee, a group led by a managing board and representatives from over 25 of the nation's federal agencies. ${ }^{94}$ NSET is a subcommittee of the larger National Science and Technology Council Committee on Technology. ${ }^{95}$ NSET uses one of its four working groups to specifically focus on health and environmental concerns surrounding nanotechnology and nanomedicine. ${ }^{96}$

NNI is funded by the federal government. It has an estimated budget of $\$ 1.5$ billion for the 2009 fiscal year. ${ }^{97} \mathrm{NNI}$ invests these federal funds in federal agencies with programs and projects specifically related to nanotechnology research and development. ${ }^{98}$ The following chart details the distribution of NNI funds to federal agencies.

92. Id.

93. Id.

94. National Nanotechnology Initiative, http:/www.nano.gov/html/ about/nniparticipants.html (last visited Jan. 16, 2009).

95. Id.

96. Nanoscale Science, Engineering and Technology (NSET) Subcommittee Working Groups, http://www.nano.gov/html/about/nsetworkinggroups.html (last visited Jan. 16, 2009).

97. National Nanotechnology Initiative FY 2009 Budget Highlights, http://www.nano.gov/NNI_FY09_budget_summary.pdf (last visited April 21, 2010); see also National Science and TEChNOLOGY CounCil, The National Nanotechnology INITIATIVE: StRATEGIC PLAN (2007), available at http:/www.nano.gov/NNI_Strategic_ Plan_2007.pdf.

98. National Nanotechnology Initiative, http://www.nano.gov/html/about/funding.html (last visited Jan. 16, 2009). 
NNI Budget 2007-200999

\begin{tabular}{|c|c|c|c|}
\hline \multicolumn{4}{|c|}{ (dollars in millions) } \\
\hline & 2007 & 2008 Estimate & 20 \\
\hline Department of Defense & 453 & E46. & and \\
\hline National Science Foundation & 389 & 389 & 397 \\
\hline Department of Energy & 236 & ins & 314 \\
\hline $\begin{array}{l}\text { Department of Health and Human } \\
\text { Services (National Institutes of } \\
\text { Health }\end{array}$ & 215 & 226 & 226 \\
\hline $\begin{array}{l}\text { Department of Commerce (National } \\
\text { Institute of Standards of Technology) }\end{array}$ & 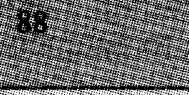 & 89 & \\
\hline $\begin{array}{l}\text { National Aeronautics and Space Ad- } \\
\text { ministration }\end{array}$ & 20 & 18 & 19 \\
\hline Environmental Protection Agency & 8 & 10 & 18 \\
\hline $\begin{array}{l}\text { Department of Health and Human } \\
\text { Services (National Institute for Oc- } \\
\text { cupational Safety and Health) }\end{array}$ & 7 & 6 & 6 \\
\hline $\begin{array}{l}\text { U.S. Department of Agriculture (For- } \\
\text { est Services) }\end{array}$ & & & \\
\hline $\begin{array}{l}\text { U.S. Department of Agriculture (Co- } \\
\text { operative State Research, Education, } \\
\text { and Extension Service) }\end{array}$ & 4 & 6 & 3 \\
\hline Department of Justice & I & 12 & 2 \\
\hline Department of Homeland Security & 2 & 1 & 1 \\
\hline $\begin{array}{l}\text { Department of Transportation (Fed- } \\
\text { eral Highway Administration) }\end{array}$ & & & \\
\hline TOTAL & 1,425 & 1,491 & 1.527 \\
\hline
\end{tabular}

Each of the above organizations has some budget/investment operations set aside for nanotechnology research and development. ${ }^{100}$ To qualify for funding an organization must have a budget/investment included under eight categories outlined in the NNI Strategic Plan. ${ }^{101}$

In addition to NNI, there are other, lesser known organizations operat-

99. National Science \& Technology Council, National Nanotechnology Initiative: FY 2009 Budget \& Highlights 1, available at http://www.nano.gov/NNI_FY09_budget _summary.pdf (last visited February 14, 2010). 2009).

100. Funding, http://www.nano.gov/html/about/funding.html (last visited Jan. 16,

101. The eight program component areas include: 1) fundamental nanoscale phenomena and process; 2) nanomaterials; 3) nanoscale devices and systems; 4) instrumentation research, meteorology and standards for nanotechnology; 5) nanomanufacturing; 6) major research facilities and instrumentation acquisition; 7) environmental health and safety; 8) and educational and societal dimensions. Funding Strategy: NNI Program Component Areas, http://www.nano.gov/html/about/fundingstrategy.html (last visited Jan. 16, 2009). 
ing in the United States that address nanotechnology. The International Association of Nanotechnology (IAN) is a non-profit international organization based in California that focuses on promotion of scientific and business development in nanotechnology. ${ }^{102}$ In contrast to IAN's goals for nanotechnology advancement, the Center for Responsible Nanotechnology (CRN) states that their purpose is "not to predict, but to prepare; not to determine exactly when and how nanotechnology will enable disruptive molecular manufacturing, but to stimulate effective preparation for it, whenever and however it comes." ${ }^{\text {"103 }}$ Unlike other previously discussed agencies, $\mathrm{CRN}$ is deeply concerned about the risks associated with nanotechnology. ${ }^{104}$ CRN attempts, however, to balance these risks against the backdrop of "cautious optimism."

\section{Opposition to Nanotechnology Research and Development in the United States}

Though nanotechnology and nanomedicine have many supporters there are other groups in the United States that are opposed to nanotechnology research and development. ${ }^{106}$ At the forefront of opposition to nanotechnology is the ETC Group - Action Group on Erosion, Technology and Concentration (name to be pronounced "et cetera"). ${ }^{107}$ The "ETC Group is dedicated to the conservation and sustainable advancement of cultural and ecological diversity and human rights." 108 Deeply concerned about the negative impacts and effects of nanotechnology, the ETC Group is calling for an evaluation of the "social implications of all nanotechnologies," and argues that "in the meantime...a moratorium should be placed on research involving molecular self-assembly and self-replication." 109

The ETC Group's skepticism about nanotechnology is motivated by a

102. International Association of Nanotechnology, http://www.ianano.org (last visited Nov. 2, 2008).

103. Center for Responsible Nanotechnology (CRN), http://www.crnano.org/index.html (last visited Nov. 2, 2008).

104. Id.

105. CRN, "Issues, Positions - and Urgency - in Nanotechnology Policy," http://www.crnano.org/positions.htm (last visit April 21, 2010).

106. "[T] $]$ he prominence of anti-nanotechnology activists...in high-level policy debates around the application of nano-engineering to the fight against global warming arguably slowed the federal government's willingness to underwrite such research." Nanowerk, Nano Tomorrows - Scenario 4 "Presidential Commission on Molecular Manufacturing Analysis: Origins of the Present Crisis," available at http://www.nanowerk.com/nanotechnology/nano tomorrows scenario4.html (last visited Nov. 2, 2008).

107. ETC Group, About ETC Group, http://www.etcgroup.org/en/about/ (last visited Nov. 2, 2008) [hereinafter About ETC].

108. Id.

109. ETC Group, Nanotechnology, http:/www.etcgroup.org/en/issues/nanotechnology.html (last visited Jan. 16, 2009). 
desire to protect underserved and underrepresented members of society. ${ }^{110}$ Specifically, they posit that nanomedicine and the large amounts of money poured into its research and development primarily benefits the wealthy. ${ }^{111}$ If nanomedicine is pursued too zealously, the ETC group argues, it could divert important funding away from programs that benefit the underserved and reduce essential health services already suffering from a scarcity of resources. ${ }^{112}$

\section{B. Regulation in the European Union}

On May 12, 2004 the European Union (EU), through the EC, issued an action entitled "Towards a European Strategy for Nanotechnology." 113 This action was created to tackle specific issues in regards to nanotechnology: offer guidelines for future policy, achieve consumer confidence in nanotechnology products, avoid health risks, create conditions for responsible development of the technology, and above all, attain these goals with the law already in existence. ${ }^{114}$ The use of "law all ready in existence" seems strikingly similar to the FDA/NTF "wait and see" approach to nanotechnology regulation.

\section{Current Regulatory Scheme}

The EU uses legislative tools called "Directives" to obtain overarching goals within each member state. ${ }^{115}$ Directives are not explicative of the means by which these goals should be obtained, but rather focus on the outcomes and goal of a Directive. ${ }^{116}$ As a result, member states implement legislation at the national level to achieve Directive goals over a period of time, usually with an articulated final deadline. ${ }^{117}$ Directives are not uniform to the entire EU, and can apply to all or only some member states. ${ }^{118}$ "Directives are used to bring different national laws into line with each oth-

110. About ETC, supra note 107.

111. ETC Group, Nanotech Rx Medical Applications of Nano-Scale TECHNOLOGIES: WHAT IMPACT ON MARGINALIZED COMMUNITIES?, 33 (2006) available at http://www.etcgroup.org/upload/publication/593/01/etc06nanotechrx.pdf.

112. Id. at 31-35.

113. Giorgia Guerra, European Regulatory Issues in Nanomedicine, 2 NANOETHICs 87, 87 (2008); see also European Commission, The European STrategy for Nanotechnology and the Nanotechnology Action Plan, http://cordis.europa.eu/nanotechnology/actionplan.htm (last visited Jan. 17, 2009).

114. Guerra, supra note 113, at 87. (Emphasis added).

115. European Commission, How EU Law is Applied - National Implementation of EU Directives, http://ec.europa.eu/community_law/directives/directives_en.htm (last visited Jan. 17,2009 ) (explaining the function and purpose of EU directives).

116. Id.

117. $I d$.

118. Id. 
er, and are particularly common in matters that affect the operation of the single market (e.g. product safety standards)." "19

"Nanobiotechnological" compositions (as they are called in the EU) generally are considered to fall under three preexisting Directive frameworks. ${ }^{120}$ The first is Directive 90/385/EEC which relates to active implantable medical devices. ${ }^{121}$ A product falls under this Directive if it is a "medical device" and both "active" and "implantable". ${ }^{22}$ The applicability of this regulation is particularly interesting because nanomedicine technologies will be implanted into the human body in some circumstances. "Implanted" means "totally or partly introduced, surgically or medically, into the human body or by medical intervention into a natural orifice, and which is intended to remain after the procedure." ${ }^{123}$

Some types of nanomedicine could potentially fall under this "implant" category, but ultimately that will depend on how nanomedicine develops. As in the Patient $\mathrm{X}$ scenario described earlier, for example, some types of nanomedicine now being researched involve the introduction of microscopic nanites into the body to perform a specific task (as in Patient $X$ 's case, to remove a tumor). Once that task has been completed, the nanites would have performed the task for which they were programmed and would at this point shut down and leave the body. Thus, the question becomes whether the nanites would qualify as sufficiently "intended to remain after the procedure" to fit within the "implant" category. ${ }^{124}$ Further, it is possible that certain nanotechnologies will be developed that are intended or able to remain in the body indefinitely after they are inserted. ${ }^{125}$

The second directive framework that nanotechnology falls under is $\mathrm{Di}$ rective 93/42/EEC - medical devices. ${ }^{126}$ This Medical Device Directive has the most general applicability to nanotechnology. ${ }^{127}$ "Medical device" is defined as "any instrument, apparatus, appliance, software, material or other article, whether used alone or in combination, including the software intended by its manufacturer to be used specifically for diagnostic and/or the-

119. Id.

120. Giorgia Guerra, A Model for Regulation of Medical Nanobiotechnology: The European Status Quo, 3 NANOTECHNOLOGY L. \& BUS. 84, 87-88 (2006) [hereinafter Guerra, $A$ Model].

121. Id.at 87 .

122. Council Directive 90/385, The Approximation of the Laws of the Member States Relating to Active Implantable Medical Devices, art. 1, 1990 O.J. (L 189) 1,3 (EN), available at http:/eur-lex.europa.eu/LexUriServ/LexUriServ.do?uri=CONSLEG:1990L0385:20071011: en:PDF (last visited Feb. 24, 2010).

123. Id.

124. Id.

125. See Keiper, supra note 27, at 20-1 (discussing theories of nanotechnology application by scientist, Kim Eric Drexler, who posits that nanotechnology will eventually be used in ways that would alter human appearance on a permanent basis if desired).

126. Guerra, supra note 113 , at 88 .

127. Id. 
rapeutic purposes and necessary for its proper application, intended by the manufacturer to be used for human beings." "The purpose of the Medical Device Directive is defined, in pertinent part, as the "....alleviation of disease," "... alleviation of or compensation for an injury or handicap," and ". . . modification of the anatomy or of a physiological process." "129 Most nanomedicine applications would fall squarely within the guidelines of $\mathrm{Di}$ rective 93/42/EEC.

The third regulation applicable to nanomedicine is Directive $98 / 79 \mathrm{EC}$ - in vitro diagnostic medical devices. ${ }^{130}$ An in vitro diagnostic medical device includes those which are:

a reagent, reagent product, calibrator, control material, kit, instrument, apparatus, equipment, or system, whether used alone or in combination, intended by the manufacturer to be used in vitro for the examination of specimens, including blood and tissue donations, derived from the human body, solely or principally for the purpose of providing information. ${ }^{131}$

In vitro is a technique in which procedures are performed on living matter outside the controlled environment of the living organism (or, in lay terms, in a test tube). ${ }^{132}$ As discussed in further depth below, nanomedicine is expected to have many applications for in vitro research and treatment. ${ }^{133}$ The EU is currently considering nanotechnology and its applications under these Directives. $^{134}$

\section{Designated Regulatory Groups and Agencies Drafting Policy}

The European Technology Platform on Nanomedicine (ETP) is spearheading the nanotechnology movement in Europe. ${ }^{135}$ The ETP website de-

128. Council Directive 93/42, Concerning Medical Devices, art. 1,1993 O.J. (L 169) 1, 5 (EN), available at http://eur-lex.europa.eu/LexUriServ/LexUriServ.do?uri=CONSLEG:1993L 0042:20071011:en:PDF (last visited Nov. 8, 2008).

129. Id.

130. Guerra, supra note 113 , at $87-88$.

131. Directive 98/79, In Vitro Diagnostic Medical Devices, art. 1, 1998 O.J. (L 331) 1, 7 (EN), available at http://eur-lex.europa.eu/LexUriServ/LexUriServ.do?uri=CONSLEG:1998L 0079:20031120:en:PDF (last visited Nov. 8, 2008).

132. Id.

133. European Technology Platform on Nanomedicine, Vision Paper and Basis for a Strategic Research Agenda for Nanomedicine, 15 (Sept. 2005) available at http://www.etpnanomedicine.eu/public/about/press-documents/publications/etp-nanomedicine-visionpaper [hereinafter ETP Strategic Research Agenda].

134. Guerra, supra note 113, at. 87-88.

135. The European Technology Platforms "[p]rovide a framework for stakeholders, led by industry, to define research and development priorities, timeframes and action plans on a number of strategically important issues where achieving Europe's future growth, competi- 
scribes the group's inception and objectives:

An important initiative, led by industry, has been set up together with the European Commission. A group of 53 European stakeholders, composed of industrial and academic experts, has established a European Technology Platform on nanomedicine. The first task of this high level group was to write a vision document for this highly future-oriented area of nanotechnology-based healthcare in which experts describe an extrapolation of needs and possibilities until 2020 . Beginning of 2006 this Platform has been opened to a wider participation (December 2006: 150 member organisations) and has delivered a so-called Strategic Research Agenda showing a well elaborated common European way of working together for the healthcare of the future trying to match the high expectations that nanomedicine has raised so far.

The ETP's 2005 Vision Document focuses on three specific areas of nanomedicine: 1) in vitro diagnostics, 2) targeted drug delivery and release (currently in public use), and 3 ) regenerative medicine. ${ }^{136}$ The Vision Document sets forth specific goals in each of the three defined areas, to be achieved by the year 2020:1) nanodiagnostics - "[m]ultimodal cameras for medical imaging," 2) targeted drug delivery - "[m]ulti-reservoir drug delivery microchips," 3) regenerative medicine - "[n]erve regeneration for spinal and limb repair."

\section{Considering Regulation}

In its 2005 Vision Document the ETP discussed the need for more research and development of nanomedicine before incorporating new language into regulation. ${ }^{138}$ It stated:

[i]t is necessary to put into place measures that identify the hazards associated with novel nanotechnology-based therapies, characterize the associated risks, reduce those risks as far as reasonably practicable, establish a positive risk/benefit balance, and communicate the nature of any residual risks and other relevant safety information to doctors, patients and other key

tiveness and sustainability objectives is dependent upon major research and technological advances in the medium to long term." European Technology Platforms, Welcome to the European Technology Platforms, available at http://cordis.europa.eu/technology-platforms/ (last visited Mar. 12, 2009).

136. ETP Strategic Research Agenda, supra note 133, at 4.

137. Id.

138. Id. 
stakeholders. $^{139}$

This language seems to indicate a framework for analysis of regulatory issues that begins with the identification of risks and ends with a reduction of those risks. ${ }^{140}$ Crucial to this framework is the dissemination of the risk/benefit analysis to patients, doctors, and decision makers. This point touches back upon the ethical concerns posed by some who deal with informed consent and a patient's ability to give such consent if the risks of nanomedicine are largely unpredictable or altogether unknown. ${ }^{141}$

\section{Focus of Research and Development}

The ETC has chosen a list of diseases on which to focus research and development of nanomedicine. It states, "[T]his Strategic Research Agenda addresses a choice of diseases, selected by their impact on patients, their prevalence and burden to society, and by the expected beneficial impact nanomedicine is likely to have on them in the near future."142 This pointed commitment to nanomedicine research and development is decidedly absent from efforts in the U.S.

\section{ANALYSIS: STRATEGY FOR GOVERNANCE OVER NANOMEDICINE}

\section{A. The Trouble with Regulating Too Early}

The first step for providing meaningful regulation of nanomedicine in the future will be a restraint on regulating the technology too early. Regulation that arrives before the technology is even fully understood or its potential fully realized will function to hinder the further development of the technology - stifling it at the outset.

\section{In the United States}

Currently, nanotechnology in the U.S. is regulated exclusively under the rubric and guidance of the FDA. ${ }^{143}$ "Potential applications [for FDA approval] are expected to include products such as drugs, medical devices, biotechnology products, tissue engineering products, vaccines, cosmetics,

139. Id.

140. Id.

141. Potential Pitfalls, supra note 36.

142. The six diseases mentioned in the Strategic Research Agenda include: cardiovascular disease, cancer, musculoskeletal disorders, neurodegenerative diseases and psychiatric conditions, diabetes, and bacterial and viral infections diseases. ETP Strategic Research Agenda, supra note 133 at 10.

143. Sadrieh \& Espandiari, supra note 57, at 340 (noting that nanotechnology will be particularly applicable in medicine and health, consumer products, as well as transportation and agriculture). 
and combination products."144 The FDA's regulatory power is far-reaching, encompassing products which "account for twenty-five cents out of each dollar that each American spends." 145 Given the FDA's broad regulatory authority, new nanotechnology will undoubtedly be subject to FDA authority, regardless of how it develops. As such, the FDA's approach to nanotechnology regulation is of utmost importance as nanomedicine develops and therefore its policies and systems of regulation should be given careful scrutiny.

After careful monitoring of current nanotechnology advancement, the FDA maintains that its "existing requirements may be adequate for most nanotechnology products" they would regulate. ${ }^{146}$ The results of recent research in nano-sized particles, however, indicate that the FDA's existing regulatory structures may not adequately address the novel problems that nanotechnology will likely pose. The unexpected behavior of silver nanoparticles discussed earlier demonstrates one of the potential weaknesses in the FDA's existing regulations for nanotechnology. ${ }^{147}$ In the silver nanoparticles research, it was discovered that electrically neutral silver nanoparticles are able to traverse plasma membranes with greater ease than their electrically-charged counterparts - a distinction not exhibited in larger electrically neutral molecules. ${ }^{148}$ The fact that these nanoparticles - which, aside from their size -- otherwise share the characteristics of larger molecules - behave differently than larger molecules indicates that traditional predictive assumptions about the behavior of new technology may not apply to nanotechnology. This uncertainty regarding the unpredictability of nanoparticles simply due to the newness of the research in the field prompted the NTF to express "a lack of confidence in currently used FDA product testing methods for safety and efficacy." 149

Others believe that current regulations, in particular those for combination products (the category into which nanotechnology is likely to fall within the FDA's regulatory guidelines), are adequate to meet the needs of this emerging technology for the following reasons: "high dose multiples are used in all studies...; at least two animal species are used...; extensive histophathology is conducted on most organs...; functional test to assess if there are effects on specific organ systems...; and drug treatments in animals can be for extended periods of time." 150 These testing requirements for combination products are thought to be rigorous enough to evaluate na-

144. Id.

145. Id.

146. FDA Nanotechnology FAQ, supra note 60.

147. Wilhelmi, supra note 5, at 102.

148. Id.

149. Id. (citing FDA, NANOTECHNOLOGY: A REPORT OF THE U.S. FOOD AND DRUG ADMINISTRATION NANOTECHNOLOGY TASK FORCE 16 (2007), available at http://www.fda.gov/ nanotechnology/taskforce/report2007.pdf.

150. Sadreih \& Espandiari, supra note 57, at 344. 
notechnology products in the foreseeable future. "As such, we do not expect that the FDA will be issuing any new guidance to specifically focus on nanotechnology products, as these products will be covered by the existing guidance documents."151

\section{In the European Union}

Discussion on the topic of nanotechnology is moving swiftly in the EU as it works toward developing a strategy for addressing issues that arise with the emerging technology. "While knowledge gaps remain regarding the potential risks of nanotechnologies, the [EC] again expressed confidence that existing EU regulation can be applied to this emerging sector, stressing that the challenge ahead lies in their implementation."152 The confidence that the EU places in the current regulation is not, however, given without pause. "Knowledge on essential questions such as characterisation of nanomaterials, their hazards, exposure, risk assessment and risk management should be improved." 153

This improvement, the EU states, will likely stem from the implementation of the regulations to nanotechnology, not the regulatory language itself. ${ }^{154}$ "Current legislation covers in principle the potential health, safety and environmental risks in relation to nanomaterials. The protection of health, safety and the environment needs mostly to be enhanced by improving the implementation of current legislation."155 Recognizing that the current regulatory language as applied to nanotechnology may be lacking in some cases, it articulates that "Commission working groups in charge of coordinating implementation of legislation are examining on an ongoing basis whether regulatory change on specific aspects is necessary, taking into account the continuously generated information linked with the identified knowledge gaps."156

Complementing the above guidelines for nanotechnology regulation in the EU, the ETC has articulated additional concerns specifically related to nanomedicine in its "Strategic Research Agenda for Nanomedicine.",157 The concerns are listed under the heading "Providing the Environment to

151. Id. at 349 (both authors of this article are employed by the FDA; as such, their opinions are unique and particularly interesting to this topic).

152. Nanowerk, European Commission Sees No Regulatory Void on Nanotechnology, Oct. 7, 2008, available at http://www.nanowerk.com/news/newsid=7617.php (last visited Sept. 29, 2009).

153. Communication from the Commission to the European Parliament, The Council and the European Economic and Social Committee, Regulatory Aspects of Nanomaterials, COM (2008) 366 final, at 11 (June 17, 2008) [hereinafter Regulatory Aspects].

154. $I d$.

155. $I d$.

156. $I d$.

157. ETP Strategic Research Agenda, supra note 133. 
Facilitate Nanomedicine" in the report. ${ }^{158}$ Including this section in the overall "Strategic Research Agenda" suggests that the EU is aware that nanomedicine may not fit well within the current regulatory guidelines. ${ }^{159}$ Further, the report specifically addresses the importance of public opinion and reception of nanomedicine. ${ }^{160}$

Another important building block for an environment in favour of nanomedicine is the public acceptance of this novel technology. So far European public opinion as expressed by the media and focus groups is largely positive because nanotechnology promises great benefits for the health and everyday life of people in addition to economic success. However, one has to be cautious not to fuel the hype about the technology, which in this regulated sector will have to mature over a prolonged period of time. ${ }^{161}$

The ETC further couches this public opinion concern focusing on the benefits European citizens will receive from nanotechnology. Such benefits include not only an enhanced quality of life because of nanomedicine, but that this enhancement of life will come at much less economic and societal costs. ${ }^{162}$

The ETC has also discussed the development of intellectual property rights for nanomedicine within the general rules in the Seventh Framework Programme (FP7). ${ }^{163}$ The FP7 was designed to group all research initiatives in the EU and classify them into four broad categories: cooperation, ideas, people, and capacities. ${ }^{164}$ Framework Programmes are proposed by the European Commission and once approved by the European Parliament, function as the primary tool through which the EU funds scientific research and development. ${ }^{165}$

"A working group composed of representatives from industry, academia, and public administration has been established to further elaborate the principles of the intellectual property policy of the European Technology Platform on Nanomedicine."166 As of 2006, this group enumerated three "model aims" to "achieve a large participation in the initiative and a fair

158. Id. at 24.

159. Id.

160. Id.

161. Id. at 20.

162. Id. at $11-14$.

163. Id. at 28; see also European Commission, Understand FP7, available at $\mathrm{http} / / /$ cordis.europa.eu/fp7/understand_en.html (last visited Feb. 12, 2009).

164. Id.

165. Id.

166. ETP Strategic Research Agenda, supra note 133. 
allocation of rights on generated intellectual property" in nanomedicine. ${ }^{167}$ First, they articulated the goal to streamline the application process for intellectual property rights so as to diminish administrative burdens by permitting only one applicant per patent. ${ }^{168}$ The second aim states that all research trials will be free from royalties. ${ }^{169}$ The third objective sets forth general goals for commercial use of the intellectual property rights. ${ }^{170}$

\section{B. Fixing the Focus on Research and Development}

The second step toward creating meaningful regulation for nanomedicine will be to shift the current focus firmly on research and development of nanotechnology. The EU has noted "a[]s knowledge becomes the critical factor for implementation and, eventually, legislation, targeted actions in a number of areas and at different levels, particularly in the field of research and development...[are] a matter of priority." ${ }^{171}$ The EU further vows that " $[t]$ hey will take into consideration work that has been carried out...at [the] national and international level."172 By not limiting its focus solely to the research and development of nanomedicine only in the EU specifically, it will be better able to facilitate "a rapid improvement of the scientific knowledge bas[e]." $" 173$

Similarly, the FDA has indicated a focus on nanotechnology research and development in the NTF report, stating "[r]apid developments in the field mean that attention to the emerging science is needed to enable the agency to predict and prepare for the types of products...in the near future." 74 They go on to describe "the need for timely development of a transparent, consistent, and predictable regulatory pathway."175

The U.S. and the EU should proceed cautiously, though, to ensure that the emerging science of nanomedicine is more completely understood before regulations are crafted. Failing to comprehend the science learned through nanomedicine research and development could lead to regulation that arrives too early. This early arrival of regulation could potentially inhibit the future of nanomedicine and stifle its development.

167. Id.

168. Id.

169. Id.

170. Id.

171. Regulatory Aspects, supra note 153, at 11.

172. Id.

173. Id.at 8.

174. NTF Report, supra note 80 , at ii.

175. Id. 


\section{Dealing with the Ethical Conundrum Surrounding the Unknown in Na- nomedicine}

The ETP raises the question of a new line that might one day need to be drawn between medical treatment and human enhancement. ${ }^{176}$ The FDA has also recognized the presence of such ethical considerations. ${ }^{177}$ Assume Patient X suffered some blindness as a side effect to the tumor. Not only can Patient X's tumor be cured by nanomedicine, so too can her blindness. What if, however, her vision is not only repaired by the nanites, but also enhanced in some way. ${ }^{178}$ Considerations such as this pose interesting and complex ethical issues over both the technology and its eventual uses.

\section{Contemporary Comparison to a Medical and Ethical Dilemma}

Nanomedicine is the most recent newcomer in a long line of medical topics that are steeped in ethical considerations. The most clear ethical issue to parallel nanotechnology is stem cell research and development. Stem cell research has faced a great deal of ethical backlash since the first human embryonic stem cells were cultured in $1998 .{ }^{179}$ Like nanomedicine, stem cells are unique and beneficial because their eventual use and application in the medical environment are limitless. ${ }^{180}$ Stem cells, particularly embryonic stem cells, are "undifferentiated cells that have the ability to form any specific adult cell." ${ }^{\text {181 }}$ Furthermore,

stem cells offer insight into human developmental events that cannot be studied directly. This insight could provide medical understanding of human development with potential clinical significance for preventing or treating birth defects, infertility, or pregnancy loss, as well as ultimately leading to the prevention or treatment of abnormal human development. Finally, stem cells could provide a valuable source of transplantable cells and tissues for repair and regeneration, ushering in a brand new era of re-

176. ETP Strategic Research Agenda, supra note 133 at 24.

177. NTF Report, supra note 80 , at 4.

178. See ETP Strategic Research Agenda, supra note 133 at 24.

179. Jordan Saltzberg, The Current Embryonic Stem Cell Research Federal Funding Policy: Undue Respect to Minority Ethical Considerations?, 29 J. LEGAL MED. 505, 505 (2008).

180. Id. at 506 (citing Embryonic Stem Cell Research at UW-Madison, available at http:// www.news.wisc.edu/packages/stemcells/facts.html (last visited Feb. 13, 2008)).

181. Saltzberg, supra note 179, at 506 (stating that embryonic stem cells could theoretically provide an unlimited supply of adult cells for a variety of uses). 
generative medicine. $^{182}$

Noting the enormous benefits to the overall health of society that the stem cell research offers, it important to identify precisely what opponents to stem cell research find so ethically repugnant. In order for a stem cell to be obtained from an embryo, the embryo must be destroyed. "Once the fertilized egg is formed [from in vitro fertilization], natural cell divisions. commence...[R]oughly five to nine days...[later], stem cells can be derived from the inner cell mass of the embryo, . . . thus destroying the developing organism and any potential for independent life it may have possessed." The destruction of the embryo is the basis for the opponent's argument they believe that to end the existence of the fertilized embryo is to end a life. ${ }^{185}$ This life, they argue, should be regarded with the same protections as a newborn baby or adult. ${ }^{186}$ Essentially it is the same argument used by opponents of abortion - Does stem cell research promote ending the life of a being that deserves the full protection of the law? Those opposed to stem cell research would argue that if that question cannot be answered with firm certainty, then this research should not receive federal support.

Not only is the topic of stem cell research sensitive on an ethical level, it is also a charged issue because many do not believe that stem cell research and development should take place with federal money. ${ }^{187}$ Stem cell research will certainly move forward with or without federal money. ${ }^{188}$ If the government chooses to not invest in the research and development, then it will have no ability to regulate the research - essentially handing over all power to the private sector. ${ }^{189}$ " "An 'unlegislated, commercially driven world' of hESC [human embryonic stem cell] research could lead to ' unsafe, black market conditions,' and erode respect for human embryonic stem cells, the very respect opponents of such research stress and which erosion could be protected against by federal regulation.",190

182. Id. (citations omitted).

183. Id.

184. Id. at 507. "[This report] summarizes some of the more interesting and significant recent developments ... both in the basic science and medical applications of stem cell research and in the related ethical, legal, and policy discussions." A REPORT OF THE PRESIDENT'S COUNCIL ON BIOETHICS, MONITORING STEM CELl RESEARCH 2 (2004), available at http://www.bioethics.gov/reports/stemcell/pcbe_final_version_monitoring_stem_cell_research.pdf (focusing on the ethical, legal, scientific, and medical developments so "that the President, the Congress, and the nation may be better informed as they consider where we should go in the future." Id.)

185. Saltzberg, supra note 179 , at 512.

186. $I d$.

187. Id. at 505 .

188. Id. at 517 .

189. Id.

190. Id. (quoting Carly Goldstein, Note, Dipping into Uncle Sam's Pockets: Federal Funding of Stem Cell Research: Is It Legal?, 11 B.U. PUB INT. L.J 229, 256 (2002)). 


\section{Creation of a Task Force on Ethical Considerations}

The U.S. and the EU should consider creating task forces to analyze and monitor the ethical considerations surrounding nanomedicine. As with stem cell research, "[e]ven ... those who favor [the] research ... [have] questions about its proper limits and the means of establishing and enforcing those limits through meaningful regulation." ${ }^{\text {"191 }}$ These task forces should be charged with determining what these "proper limits" will include and how nanomedicine can be developed and implemented in the future.

\section{CONCLUSION}

Though nanotechnology and nanomedicine are still firmly situated in the research and development phase, the United States and the European Union have both decided to preemptively examine this emerging technology. Both countries are proceeding cautiously, however, with regard to regulation of this new technology. Through adoption of "wait and see" approaches, the nations will be better situated to meaningfully deal with and regulate the technology once the science is fully understood, and there is a clear defined direction in which the technology will be used.

It will not be until these scientific advancements occur that the governments will be able to adequately see the limitations of the application of current regulatory structures already in place as they apply to nanotechnology and nanomedicine. Once these limitations are adequately realized, it will be possible for meaningful regulation to follow. The future of meaningful regulation will only stem from careful monitoring of the research and development of nanotechnology. Though some of the current regulations might adequately govern parts of nanotechnology and nanomedicine in the future, it is likely that these regulations will not be able to address all of issues as most are not yet known.

In addition to focusing on the science of nanomedicine, the United States and the European Union should consider creating ethical task forces. These task forces would be charged with monitoring potential ethical issues surrounding the eventual uses for nanotechnology and nanomedicine. They will likely have to tackle such issues as nanomedicine uses for human enhancement in addition to countless ethical considerations that have not been

191. A Report of the President's Council on Bioethics, Monitoring Stem Cell RESEARCH 6 (2004), available at http:/www.bioethics.gov/reports/stemcell/ pcbe_final_version_monitoring_stem_cell_research.pdf "Much basic and applied research remains to be done if human stem cells are to achieve their promise in regenerative medicine. This research is expensive and technically challenging, and requires scientists willing to take a long perspective in order to discover, through painstaking research, which combinations of techniques could...be successful." Id. at 140 (noting that this could not be accomplished without "strong financial support" from both public and private sources). 
imagined or contemplated at this point.

Much like stem cell research, nanomedicine technology raises specific ethical considerations that must be explored and considered when contemplating the regulation of not only its research and development, but also its inevitable use in society. The governments of the United States and the European Union both have pivotal roles to play in the regulation of this research. This influence will ultimately determine how nanotechnology develops and is eventually used in society.

Nanotechnology and nanomedicine have the potential to revolutionize the medical field in many beneficial ways. Nanotechnology is quickly moving beyond the walls of laboratories, where it is constrained by theory, and is shifting ever closer to the realm of practical applicability. As this shift occurs, governments of leading nations need to remain watchful over nanotechnology and nanomedicine developments. Current regulatory structures for medical devices and technology may initially be an appropriate platform from which to govern nanomedicine. The technology, however, may quickly outgrow the effectiveness of these regulations.

The United States and the European Union should continue to employ the "wait and see" approach to nanotechnology and nanomedicine regulation until more is learned from research and development. As the science takes shape, the governments should use specific task forces to pointedly consider the ethical issues surrounding human enhancement and other ethical issues that develop with the technology. Through understanding and preparation on the ethical issues involved, governments will be better able to frame a meaningful regulatory structure for nanotechnology and nanomedicine. This regulatory structure will determine future societal uses of this technology. The governments of the United States and the European Union must remain mindful of the critical role they are to play as some of the most important technology of the future begins to develop. "The decision...reach[ed] here today will determine how we will regard this creation of our genius. It will reveal the kind of people we are; what...[we are] destined to be." 192

192. Star Trek the Next Generation: The Measure of a Man (Paramount Television Broadcast February 13, 1989). 